\title{
PENATALAKSANAAN PENYAKIT JANTUNG TIROID
}

\author{
Frans E. Wantania \\ Bagian/SMF Ilmu Penyakit Dalam Divisi Kardiologi \\ Fakultas Kedokteran Universitas Sam Ratulangi Manado \\ Email: wantaniaerwinfrans@yahoo.com
}

\begin{abstract}
Thyroid heart disease is a heart disease caused by the effect of thyroid hormone. The incidence is still high among general population and may affect people of all ages. The most common etiology is Graves's disease that occurs frequently in adults from 20-40 years of age. Thyroid hormone increases the total body metabolism and oxygen consumption that indirectly lead to an increased cardiac workload. The certain mechanism has not been fully understood, however, thyroid hormone may lead to an inotropic and chronotropic cardiac effects similarly to adrenergic stimulation effect. Patients commonly have palpitation and dyspnea. In elderly with coronary arterial disease, angina pectoris may occur simultaneously with the onset of hyperthyroidism. In addition, patients with hyperthyroidism may show symptoms of heart failure without any signs of heart disease before. The diagnosis of thyroid heart disease is based on the thyroid hormone levels i.e. high FT4 and low TSHs, meanwhile the diagnosis of heart failure due to complications of the hyperthyroidism is established by Framingham criteria that require either 2 major, or 1 major and 2 minor criteria. The treatment includes immediate decreasing of the hypermetabolic condition by administration of antithyroid drugs, and managing cardiovascular manifestation inter alia by reducing the heart rate and administration of antihypertensive drugs.
\end{abstract}

Keywords: thyroid heart disease, diagnosis, treatment

Abstrak: Penyakit jantung tiroid adalah penyakit jantung yang disebabkan oleh pengaruh hormon tiroid. Insiden penyakit ini cukup tinggi di masyarakat dan dapat mengenai segala usia. Penyebab terbanyak ialah struma difus toksik (penyakit Graves), biasanya mengenai usia 20 - 40 tahun. Hormon tiroid meningkatkan metabolisme tubuh total dan konsumsi oksigen yang secara tidak langsung meningkatkan beban kerja jantung. Mekanisme secara pasti belum diketahui namun diketahui bahwa hormon tiroid menyebabkan efek inotropik dan kronotropik yang mirip dengan efek stimulasi adrenergik. Pasien sering mengalami palpitasi, irama jantung yang tidak teratur, dan sesak saat beraktivitas. Pada pasien lanjut usia yang memiliki dasar penyakit arteri koroner, angina pektoris dapat terjadi bersamaan dengan onset hipertiroidisme. Selain itu, pasien dengan hipertiroidisme dapat menunjukkan tanda-tanda gagal jantung kongestif tanpa kelainan jantung sebelumnya. Diagnosis penyakit jantung tiroid dapat ditegakkan dan dipastikan dengan pemeriksaan kadar hormon tiroid bebas, yaitu kadar FT4 yang tinggi dan TSH yang sangat rendah. Gagal jantung sebagai akibat komplikasi hipertiroid dapat ditegakkan dengan menggunakan kriteria Framingham, yaitu bila gejala dan tanda gagal jantung memenuhi 2 kriteria mayor, atau 1 kriteria mayor ditambah 2 kriteria minor. Penatalaksanaan penyakit kardiovaskular pada hipertiroidisme ialah secepatnya menurunkan kondisi hipermetabolik dengan pemberian obat antitiroid untuk menurunkan kadar hormon tiroid dan menangani manifestasi kardiovaskular lainnya seperti menurunkan kecepatan irama jantung dan pemberian obat-obatan anti hipertensi.

Kata kunci: penyakit jantung tiroid, diagnosis, penatalaksanaan 
Penyakit jantung tiroid adalah penyakit jantung yang disebabkan oleh pengaruh hormon tiroid. Pengaruh biokimiawi hormon tiroid pada jantung terjadi terutama pada hipertirodisme. Hipertiroidisme adalah hiperfungsi tiroid, yaitu peningkatan biosintesis dan sekresi hormon oleh kelenjar tiroid. ${ }^{1}$

Insiden penyakit jantung tiroid cukup tinggi di masyarakat dan dapat mengenai segala usia. Insiden diperkirakan 0,4 per 1000 wanita per tahun, lebih sering pada wanita dibandingkan pria dengan perbandingan 4:1, terutama pada usia 30-50 tahun; $15 \%$ terjadi pada usia diatas 60 tahun dan 70\% disebabkan oleh penyakit Graves yang berakibat meningkatnya angka kematian dan angka kesakitan kardiovaskuler. ${ }^{2}$

Gejala dan tanda gagal jantung meliputi sesak nafas terutama pada malam hari, batuk malam hari, sesak saat beraktivitas, distensi vena leher, ronki kardiomegali, edema paru akut, suara jantung ketiga, refluks hepatojugular, edema ekstremitas, hepatomegali, efusi pleura, penurunan kapasitas vital sepertiga normal, dan takikardi. ${ }^{3,4}$

Pemeriksaan laboratorium yang diperlukan ialah pemeriksaan kadar free $\mathrm{T} 4$ (FT4) dan thyroid stimulating hormone (TSH) untuk hipertiroid. Pemeriksaan penunjang lainnya yang dibutuhkan ialah foto toraks, elektrokardiografi, dan ekokardiografi untuk melihat gangguan pada jantung. ${ }^{5}$

Diagnosis ditegakkan berdasarkan anamnesis, pemeriksaan fisik, pemeriksaan laboratorium serta pemeriksaan penunjang. Diagnosis penyakit jantung hipertiroid dapat ditegakkan dan dipastikan dengan pemeriksaan kadar hormon tiroid bebas, yaitu kadar FT4 yang tinggi dan TSH yang sangat rendah. Gagal jantung sebagai akibat komplikasi hipertiroid dapat ditegakkan dengan menggunakan kriteria Framingham. ${ }^{6}$ Penatalaksanaan penyakit kardiovaskular pada hipertiroidisme ialah secepatnya menurunkan kondisi hipermetabolik dengan pemberian obat antitiroid untuk menurunkan kadar hormon tiroid dan menangani manifestasi kardiovaskular lainnya seperti menurunkan kecepatan irama jantung dan pemberian obat-obatan anti hipertensi. ${ }^{1,7}$

\section{ETIOPATOGENESIS}

Prevalensi data dari Whickham Survey pada pemeriksaan penyaring dengan menggunakan free thyroxine index (FT4I) menunjukkan hipertiroidisme pada masyarakat sebanyak 2\%. Pada wanita ditemukan 2027 kasus per 1.000 wanita, sedang pria 1-5 per 1.000 pria. Umumnya usia penderita antara 20-50 tahun. ${ }^{6,8}$ Penyebab terbanyak ialah struma difus toksik (penyakit Graves), biasanya mengenai usia 20-40 tahun. Penyebab lainnya ialah adenoma toksik dan struma multinodosa toksik. ${ }^{9}$ Prevalensi struma multinodosa toksik meningkat dengan usia dan menjadi penyebab utama hipertiroidisme pada orang tua. ${ }^{10}$

Hormon tiroid sangat memengaruhi sistem kardiovaskular dengan beberapa mekanisme, baik secara langsung maupun tidak langsung. Hormon tiroid meningkatkan metabolisme tubuh total dan konsumsi oksigen yang secara tidak langsung meningkatkan beban kerja jantung. Mekanisme secara pasti belum diketahui namun diketahui bahwa hormon tiroid menyebabkan efek inotropik, kronotropik, dan dromotropik yang mirip dengan efek stimulasi adrenergik. ${ }^{1,11}$

Efek hormon tiroid terhadap sel nuklear terutama dijembatani melalui perubahan penampilan gen yang responsif. Proses ini dimulai dengan difusi T4 dan T3 melintasi membran plasma karena mudah larut dalam lemak. Di dalam sitoplasma, T4 dirubah menjadi T3 oleh 5-monodelodinase, konsentrasinya bervariasi dari jaringan ke jaringan, yang merupakan hubungan tidak langsung sebagai respons jaringan terhadap hormon tiroid. Selanjutnya, T3 sirkulasi dan T3 yang baru disintesis melalui membran nukleus untuk berikatan dengan reseptor hormon tiroid spesifik (THRs). ${ }^{1}$

Secara anatomis, hormon tiroid dapat mengakibatkan hipertrofi jantung sebagai akibat meningkatnya sintesis protein. Peningkatan isi semenit disebabkan oleh 
peningkatan frekuensi denyut jantung dan isi sekuncup, penurunan resistensi perifer, dan adanya vasodilatasi perifer akibat pemanasan karena peningkatan metabolisme jaringan. ${ }^{1}$ Pengaruh hormon tiroid pada hemodinamik jantung dapat juga terjadi akibat meningkatnya kontraktilitas otot jantung. Pada tirotoksikosis, sirkulasi yang meningkat mirip dengan keadaan meningkatnya kegiatan adrenergik. Hal ini bukan disebabkan oleh meningkatnya sekresi katekolamin, karena kadar katekolamin justru turun pada tirotoksikosis. Keadaan ini disebabkan oleh meningkatnya kepekaan jaringan terhadap katekolamin. Pada sistem hantaran, hormon tiroid menyebabkan meningkatnya kecepatan hantaran atrium dan memendeknya masa refrakter yang tak dapat dipengaruhi oleh katekolamin. Sinus takikardia terjadi $40 \%$ pasien dengan hipertiroidisme dan 10 - 15\% dapat terjadi fibrilasi atrial persisten. ${ }^{12,13}$

Pada penyakit jantung akibat hipertiroidisme tidak dijumpai kelainan histopatologik yang nyata, kecuali adanya dilatasi dan hipertrofi ventrikel. Umumnya, gagal jantung pada pasien hipertiroidisme terjadi pada dekade akhir kehidupan dengan insiden tinggi terjadinya penyakit jantung koroner. Kemungkinan peran hormon tiroid dalam mengakibatkan gagal jantung melalui peningkatan kebutuhan oksigen pada pasien yang sudah mengalami kekurangan penyediaan oksigen akibat penyakit jantung koroner. Keadaan pasien yang berat biasanya dihubungkan dengan hipertiroidisme yang telah berlangsung lama dengan kontraktilitas otot jantung yang buruk, isi semenit yang rendah, dan gejala serta tanda gagal jantung. ${ }^{14}$

\section{MANIFESTASI KLINIS}

Parry dan Graves menemukan bahwa hiperfungsi kelenjar tiroid didominasi oleh gejala-gejala kardiovaskular. Studi pada binatang percobaan dan manusia memperlihatkan bahwa pengaruh kelebihan hormon tiroid mengakibatkan meningkatnya kebutuhan oksigen, kerja inotropik, kerja kronotropik, dan pintas arteri-vena perifer.
Dengan kateterisasi jantung dapat dibuktikan bahwa peningkatan hormon tiroid ini mengakibatkan peningkatan frekuensi denyut jantung, isi semenit, waktu curah rata-rata ventrikel kiri, aliran darah koroner, dan meningkatnya kebutuhan oksigen. ${ }^{1}$

Pasien dengan penyakit jantung tiroid sering mengeluhkan gejala-gejala yang berkaitan dengan perubahan kronotropik. Pasien sering mengalami palpitasi, irama jantung yang tidak teratur, dan dispnea saat beraktivitas. Pada pasien lanjut usia yang memiliki dasar penyakit arteri koroner, angina pektoris dapat terjadi bersamaan dengan onset hipertiroidisme. Selain itu, pasien dengan hipertiroidisme dapat menunjukkan tanda-tanda gagal jantung kongestif tanpa kelainan jantung sebelumnya. ${ }^{11,15}$

Masalah irama jantung yang paling sering ditemukan pada hipertiroidisme ialah sinus takikardia. Peningkatan denyut jantung $>90 \mathrm{x} /$ menit terjadi pada saat istirahat atau selama tidur dan respon berlebihan jantung ditemukan selama berolahraga. Masalah berat ditemukan pada pasien dengan hipertiroidisme dan atrial fibrillation (AF) rapid ventricular response karena dapat menyebabkan kardiomiopati. Pemeriksaan fungsi tiroid harus secepatnya dilakukan pada pasien dengan onset baru AF meskipun hanya $<1 \%$ dari pasien tersebut yang memiliki bentuk subklinis atau klinis hipertiroidisme. ${ }^{15}$ Umumnya pasien dengan hipertiroidisme dan AF bisa dikonversi ke irama sinus dalam waktu 8 sampai 10 minggu setelah dimulai pengobatan. Bentuk lain dari aritmia jarang terjadi. Pasien yang mengalami keterlambatan dalam konduksi intraventrikular insidennya $<15 \%$. Blok atrioventrikular mungkin terjadi, tetapi sangat jarang ditemukan. ${ }^{16,17}$

\section{DIAGNOSIS}

Pemeriksaan laboratorium yang sering dilakukan untuk mendiagnosis hipertioridisme ialah pemeriksaan TSHs, kadar FT4, dan FT3. Pemeriksaan TSHs serum 
merupakan penunjang diagnosis hipertiroidisme yang paling handal saat ini dimana kadar TSHs pada hipertiroidisme rendah atau tidak terdeteksi, dengan FT4 yang tinggi diatas normal. Bila kadar FT4 normal maka harus diperiksa FT3 untuk menentukan tirotoksikosis T3. Bila T3 normal maka keadaan ini yang disebut dengan hipertiroidisme subklinis ${ }^{16}$ Indeks klinis Wayne sudah dikenal sejak lama dan sangat membantu mendiagnosis hipertiroidisme dengan tingkat akurasi sebesar 85\%. Skor tersebut berkisar dari +45 sampai -25. Skor yang lebih besar dari 19 menunjukkan hipertiroidisme sedangkan skor kurang dari 11 menunjukkan eutiroidisme dan skor antara 11 dan 19 masih ragu-ragu (Tabel 1). ${ }^{18}$

Tabel 1. Skoring menggunakan indeks Wayne. $^{18}$

\begin{tabular}{lllcc}
\hline $\begin{array}{l}\text { Symptoms of } \\
\text { recent onset and } \\
\text { or increased }\end{array}$ & Score Signs & Present & Absent \\
severity & & & & \\
\hline Dyspnea on effect & +1 & Palpable thyroid & +3 & -3 \\
Palpitations & +2 & Bruit over thyroid & +2 & -2 \\
Tiredness & +2 & Exophthalmoses & +2 & \\
Preference for heat & -5 & Lid retraction & +2 & - \\
Preference for cold & +5 & Lid lag & +1 & - \\
Excessive sweating & +3 & Hyperkinesis & +4 & -2 \\
Nervousness & +2 & Hands hot & +2 & -2 \\
Appetite: increased & +3 & Hands moist & +1 & -1 \\
Appetite: decreased & -3 & Casual pulse rate: & - & -3 \\
& & $>80 /$ min & & \\
Weight increased & -3 & $>90 /$ min & +3 & - \\
Weight decreased & +3 & Atrial fibrilation & +4 & - \\
\hline
\end{tabular}

Pemeriksaan penunjang yang diperlukan untuk menegakkan diagnosis ialah pemeriksaan foto toraks postero-anterior, elektrokardiografi, dan ekokardiografi. Gambaran radiologik umumnya normal, kadang- kadang dijumpai pembesaran aorta asenden dan desenden, penonjolan segmen pulmonal, dan pada kasus yang berat dijumpai pula pembesaran jantung. Pada pemeriksaan elektrokardiografi sering dijumpai gangguan irama dan kadangkadang juga ditemukan gangguan hantaran. Pada kasus yang berat dapat dijumpai pembesaran ventrikel kiri yang menghilang setelah pengobatan. Pemeriksaan ekokardiografi dapat menunjukkan insufisiensi mitral dan trikuspid. ${ }^{19}$

Diagnosis penyakit jantung tiroid dapat ditegakkan dan dipastikan dengan pemeriksaan kadar hormon tiroid bebas, yaitu kadar FT4 yang tinggi dan TSHs yang sangat rendah. Menurut Bayer MF, kombinasi hasil pemeriksaan laboratorium TSHs yang tak terukur atau subnormal dan FT4 yang meningkat jelas menunjukkan hipertirodisme. Gagal jantung sebagai akibat komplikasi hipertiroidisme dapat ditegakkan dengan menggunakan kriteria Framingham, yaitu bila gejala dan tanda gagal jantung memenuhi 2 kriteria mayor atau 1 kriteria mayor ditambah 2 kriteria minor. 6,20

\section{PENATALAKSANAAN}

Penatalaksanaan hipertiroidisme dengan komplikasi kardiovaskular memerlukan pendekatan yang berbeda, yaitu dengan mempertimbangkan faktor kardiovaskular tersebut. Tujuan pengobatan ialah secepatnya menurunkan keadaan hipermetabolik dan kadar hormon tiroid yang berada dalam sirkulasi. Keadaan sirkulasi hiperdinamik dan aritma atrial akan memberikan respon baik dengan pemberian obat penyekat beta. Dalam hal ini, propanolol merupakan obat pilihan karena bekerja cepat dan mempunyai keampuhan yang sangat besar dalam menurunkan frekuensi denyut jantung. Selain itu, penghambat beta dapat menghambat konversi T4 menjadi T3 di perifer. Pada pasien dengan gagal jantung berat, penggunaan obat penyekat beta harus dengan sangat hati-hati karena dapat memperburuk fungsi miokard, meskipun beberapa penulis mendapat hasil baik pada pengobatan pasien gagal jantung akibat tirotoksikosis. Bahaya lain dari obat penyekat beta ialah dapat menimbulkan spasme bronkial, terutama pada pasien dengan asma bronkial. Dosis yang diberikan berkisar antara 40-160 mg per hari dibagi 3-4 kali pemberian. $^{1,17}$ 
Obat antitiroid yang banyak digunakan ialah PTU dan imidazol (metimazol, tiamazol, dan karbimazol). Kedua obat ini termasuk dalam golongan tionamid yang kerjanya menghambat sintesis hormon tiroid, tetapi tidak memengaruhi sekresi hormon tiroid yang sudah terbentuk. Propiltiourasil mempunyai keunggulan mencegah konversi T4 menjadi T3 di perifer. Dosis awal PTU yang digunakan ialah 300-600 mg/hari dengan dosis maksimal 1200-2000 mg/hari atau metimazol 30-60 mg sehari. Perbaikan gejala hipertiroidisme biasanya terjadi dalam 3 minggu dan eutiroidisme dapat tercapai dalam 6-8 minggu. ${ }^{1}$

Pada pasien dengan hipertiroidisme dan AF, terapi awal harus difokuskan pada kontrol irama jantung dengan menggunakan penyekat beta (propanolol, atenolol, bisoprolol), tetapi konversi ke irama sinus sering terjadi secara spontan bersamaan dengan pengobatan hipertiroidisme. ${ }^{17}$ Pemberian penyekat beta pada kasus hipertiroidisme terkait dengan gagal jantung, harus diberikan sedini mungkin. Golongan obat penyekat beta dapat mengontrol takikardia, palpitasi, tremor, kecemasan, dan mengurangi aliran darah ke kelenjar tiroid. ${ }^{1}$ Tujuan terapi dengan penyekat beta ialah menurunkan denyut jantung ke tingkat mendekati normal dan kemudian meningkatkan perbaikan komponen disfungsi ventrikel kiri (LV). Penggunaan bisoprolol memiliki efek menguntungkan pada kasus gagal jantung dengan AF karena berhubungan dengan remodeling dari ventrikel kiri dan terdapat peningkatan signifikan left ventricle ejection fraction (LVEF). ${ }^{21}$

Jika AF berlanjut, pertimbangan harus diberikan untuk antikoagulasi, terutama pada pasien yang berisiko tinggi terhadap emboli. Terapi antikoagulan pada pasien hipertiroidisme dengan AF masih kontroversial. Frekuensi rata-rata insiden tromboemboli pada pasien hipertiroidisme sekitar 19\%. Beberapa peneliti tidak merekomendasikan pemberian obat antikoagulan pada pasien usia muda dengan durasi AF yang pendek (kurang dari 3 bulan) dan tanpa kelainan jantung oleh karena konversi ke irama sinus akan terjadi setelah diterapi dengan obat antitiroid. Pasien dengan AF kronik dan mempunyai kelainan jantung organik, berisiko tinggi terjadinya emboli sehingga merupakan indikasi pemberian antikoagulan. $^{22,23}$ Jika AF belum teratasi, perlu dilakukan kardioversi setelah 16 minggu telah menjadi eutiroidisme. Perlindungan antikoagulan terus diberikan sampai 4 minggu setelah konversi. ${ }^{1}$

Risiko kejadian tromboemboli dan strok pada pasien dengan AF tidaklah sama. Terdapat berbagai faktor klinis lain yang turut berkontribusi terhadap risiko tersebut. ${ }^{23}$ Salah satu model yang paling populer dan sukses dalam identifikasi pencegahan primer pasien dengan risiko tinggi strok ialah indeks risiko CHA2DS2-VASc (Congestive heart failure, Hypertension, Age >75 years, Diabetes mellitus, and prior Stroke or transient ischaemic attack/TIA, Vascular disease, Age 65-74, Sex category) (Tabel 2).

Tabel 2. Skor CHA2DS2-VASc. ${ }^{22}$

\begin{tabular}{|c|c|c|}
\hline & Condition & Points \\
\hline $\mathbf{C}$ & Congestive heart failure & 1 \\
\hline $\mathbf{H}$ & $\begin{array}{l}\text { Hypertension } \mathrm{BP}>140 / 90 \\
\text { or treated hypertension or on } \\
\text { medication }\end{array}$ & 1 \\
\hline $\mathbf{A}_{2}$ & Age $\geq 75$ years & 2 \\
\hline $\mathbf{D}$ & Diabetes Mellitus & 1 \\
\hline $\mathbf{S}_{2}$ & $\begin{array}{l}\text { Prior Stroke or TIA or } \\
\text { Thromboembolism }\end{array}$ & 2 \\
\hline $\mathbf{V}$ & $\begin{array}{l}\text { Vascular disease (e.g. MI, } \\
\text { PVD, aortic plaque) }\end{array}$ & 1 \\
\hline $\mathbf{A}$ & Age 65-74 years & 1 \\
\hline $\mathbf{S}_{\mathrm{c}}$ & Sex category (female gender) & 1 \\
\hline
\end{tabular}


Tabel 3. Risiko perdarahan menurut skoring HAS-BLED. ${ }^{22,24}$

HAS-BLED

\begin{tabular}{|c|c|c|}
\hline \multicolumn{3}{|c|}{$\begin{array}{l}\text { Clinical characteristics comprising the HAS-BLED } \\
\text { bleeding risk score }\end{array}$} \\
\hline Letter & Clinical characteristic ${ }^{a}$ & Points awarded \\
\hline $\mathbf{H}$ & Hypertension & 1 \\
\hline A & $\begin{array}{l}\text { Abnormal renal and liver } \\
\text { function ( } 1 \text { point each) }\end{array}$ & 1 or 2 \\
\hline S & Stroke & 1 \\
\hline B & Bleeding & 1 \\
\hline L & Labile INRs & 1 \\
\hline$E$ & Elderly (e.g. age $>65$ years) & 1 \\
\hline $\mathrm{D}$ & $\begin{array}{l}\text { Drugs or alcohol ( } 1 \text { point } \\
\text { each) }\end{array}$ & 1 or 2 \\
\hline
\end{tabular}

Indeks risiko CHA2DS2-VASc merupakan suatu sistem skoring kumulatif yang memrediksi risiko strok pada pasien dengan AF. Antikoagulan diperlukan untuk skor CHA2DS2-VASc lebih dari atau sama dengan 2, dengan mempertimbangkan risiko perdarahan (Tabel 3). 22,24

Pada pasien hipertiroidisme dengan gagal jantung, terapi diuretik digunakan untuk mengatasi kelebihan cairan, tetapi pengobatan awal harus mencakup pemberian penyekat beta. ${ }^{23}$ Terapi rutin untuk gagal jantung, termasuk inhibitor ACE, harus digunakan pada pasien yang sudah dideteksi adanya disfungsi LV atau pada pasien gagal jantung yang tidak membaik ketika detak jantung menjadi normal. ${ }^{17}$

Terapi tambahan yang dapat diberikan untuk memperbaiki metabolisme miosit jantung ialah penggunaan Ko-enzim-10 dan Trimetazidin. Ko-enzim Q-10 (CoQ10) merupakan suatu nutrien yang berperan vital dalam bioenergetik otot jantung yaitu sebagai kofaktor produksi adenosin trifosfat (ATP) mitokondrial. Efek bioenergetik CoQ10 ini sangat penting dalam aplikasi klinik, terutama hubungannya dengan sel-sel yang mempunyai kebutuhan metabolik sangat tinggi seperti miosit jantung. Nutrien ini merupakan antioksidan poten yang memiliki implikasi penting dalam fungsi jantung terutama pada kondisi cedera iskemia reperfusi pada miokard. Ko-enzim Q10 dapat memengaruhi perjalanan penyakit kardiovaskular dengan mempertahankan fungsi optimal dari miosit dan mitokondria. ${ }^{25}$ Trimetazidin telah diketahui sejak lama efektif pada penatalaksanaan angina melalui efek penghambatan rantai panjang 3-ketoasil koenzim A tiolase mitokondria yang menghambat metabolisme asam lemak sehingga dapat mengubah metabolisme energi. Keadaan ini akan menstimulasi penggunaan glukosa dan akan memroduksi ATP dengan konsumsi oksigen yang lebih rendah. ${ }^{26}$

Untuk penanganan hipertiroidismenya, pada awal pengobatan, pasien dikontrol setelah 4-6 minggu. Setelah tercapai eutiroidisme, pemantauan dilakukan setiap 3-6 bulan sekali terhadap gejala dan tanda klinis, serta laboratorium (FT4 dan TSHs). Dosis obat antitiroid dikurangi dan dipertahankan dosis terkecil yang masih memberikan keadaan eutiroidisme selama 12-24 bulan. Pengobatan kemudian dihentikan dan dinilai apakah telah terjadi remisi, yaitu bila setelah 1 tahun obat antitiroid dihentikan, pasien masih dalam keadaan eutiroidisme, walaupun kemudian hari dapat tetap eutiroidisme atau terjadi relaps. $^{27}$ 


\section{KRISIS TIROID}

Krisis tiroid (thyroid storm) ialah tirotoksikosis yang amat membahayakan, meskipun jarang terjadi. Hampir semua kasus diawali faktor pencetus dan memerlukan diagnosis dan penanganan segera dan adekuat untuk menurunkan angka kesakitan dan kematian akibat kelainan ini. Angka kematian orang dewasa mencapai $10-20 \%$. Keadaan ini paling sering terjadi pada wanita muda, namun dapat juga pada pria dan semua kelompok usia. ${ }^{28}$

Krisis tiroid biasanya dipicu oleh kondisi akut antara lain: infeksi, trauma, hipoglikemi, stres emosi, terapi iodium radioaktif, tromboemboli paru, palpasi tiroid terlalu kuat, operasi, zat kontras beriodium, persalinan, penghentian obat antitiroid, ketoasidosis diabetikum, kecelakaan, atau gangguan serebrovaskular. Kondisi yang paling sering memresipitasi terjadinya krisis tiroid ialah infeksi, khususnya infeksi paru. ${ }^{29}$

Umumnya, pasien yang diduga mengalami krisis tiroid mempunyai riwayat penyakit hipertiroidisme dengan gejalagejala yang khas. Panas tinggi merupakan gambaran khas pada sebagian besar kasus krisis tiroid karena pada krisis tiroid terdapat peningkatan basal metabolic rate (BMR) 2 kali dibanding keadaan sebelum krisis. ${ }^{30}$ Pasien juga disertai psikosis atau penurunan kesadaran dengan riwayat perilaku sebelumnya normal. Kadangkadang kebingungan, apatis emosional, kelemahan ekstrim, tanda dan gejala dekompensasi dari berbagai sistem organ dapat hadir. Pada pemeriksaan fisik didapatkan: tanda dan gejala hipertiroidisme baik oleh sebab Graves atau yang lain, sistem saraf sentral terganggu (seperti delirium dan koma), demam tinggi sampai $40^{\circ} \mathrm{C}$, takikardia sampai $130-200 \mathrm{x} /$ menit, sering terdapat AF dengan respon ventrikular cepat dan bisa memperlihatkan gagal jantung kongestif. Sering ditemukan kesulitan dalam menentukan apakah panas tinggi dan takikardia merupakan petunjuk awal terjadinya krisis tiroid atau hanya tanda adanya infeksi semata. Kecurigaan terjadinya krisis tiroid didasarkan 3 triad yaitu menghebatnya tanda-tanda tirotoksikosis, kesadaran menurun, dan hipertermia.

Penatalaksanaan sama seperti pada pasien dengan hipertiroidisme, hanya saja dosis obat yang diberikan lebih tinggi. Untuk blokade produksi hormon tiroid digunakan PTU dosis 300 mg tiap 4-6 jam atau metimazol 20-30 mg tiap 4 jam. Solusio lugol digunakan untuk blokade ekskresi hormon tiroid dengan dosis 8 tetes tiap 6 jam. Pada pasien dengan krisis tiroid harus segera ditangani di instalasi gawat darurat (ICU). Secara umum penanganan awal dapat diberikan cairan untuk rehidrasi dan koreksi elektrolit $\mathrm{NaCL}$, cairan lain dan kalori (glukosa), vitamin, oksigen, bila perlu obat sedasi. Propanolol merupakan obat pilihan pertama yang digunakan sebagai terapi inisial, bisa diberikan secara intravena atau oral. Dosis yang diberikan $1 \mathrm{mg} / \mathrm{menit}$ sampai beberapa mg hingga efek yang diinginkan tercapai atau 2-4 $\mathrm{mg} / \mathrm{jam}$ secara intravena atau $60-80 \mathrm{mg} / 4$ jam secara oral. ${ }^{31}$ Pemberian hidrokortison $100 \mathrm{mg}$ tiap 8 jam (atau deksametason 2 mg tiap 6 jam), sangat diperlukan pada setiap penanganan krisis tiroid. Rasional pemberian ialah karena adanya defisiensi steroid akibat hipermetabolisme dan untuk menghambat konversi perifer T4. Bila pasien refrakter terhadap terapi di atas maka dapat dilakukan plasmaferesis. Setelah faktor pencetus diatasi, respon pasien umumnya akan terlihat membaik dalam 24 jam, meskipun ada yang berlanjut hingga seminggu. Prognosis baik jika diagnosis ditegakkan secara dini dengan penanganan yang adekuat. ${ }^{32}$

\section{SIMPULAN}

Diagnosis penyakit jantung tiroid dapat ditegakkan dan dipastikan dengan pemeriksaan kadar hormon tiroid bebas, yaitu kadar FT4 yang tinggi dan TSH yang sangat rendah. Gagal jantung akibat komplikasi hipertiroidisme dapat ditegakkan dengan menggunakan kriteria Framingham, yaitu bila gejala dan tanda 
gagal jantung memenuhi 2 kriteria mayor, atau 1 kriteria mayor ditambah 2 kriteria minor. Penatalaksanaan penyakit kardiovaskular pada hipertiroidisme ialah secepatnya menurunkan kondisi hipermetabolik dengan pemberian obat antitiroid untuk menurunkan kadar hormon tiroid dan menangani manifestasi kardiovaskular lainnya seperti menurunkan kecepatan irama jantung dan pemberian obat-obatan antihipertensi, serta pemberian antikoagulan bagi pasien dengan risiko tinggi strok.

\section{DAFTAR PUSTAKA}

1. Antono D, Kisyanto Y. Penyakit Jantung Tiroid. In: Sudoyo AW, Setiyohadi B, Alwi I, Simadibrata M, Setiati S, editors. Buku Ajar Ilmu Penyakit Dalam Jilid II (Edisi Kelima). Jakarta: Pusat Penerbitan Ilmu Penyakit Dalam, 2009; p. 1798-1800.

2. Pittas A, Lee S. Evaluation of thyroid function. In: Hall J, Nieman L, editors. Handbook of Diagnostic Endocrinology. New Jersey: Humana Press, 2003.

3. Greenspan FS. Thyroid gland. In: Greenspan FS, Gardner DG, editors. Basic and Clinical Endocrinology (Sixth Edition). New York: McGraw Hill, 2004; p. 215-94.

4. Jameson JL, Weetman AP. Disorders of the thyroid gland. In: Braunwald E, Fauci AS, Kasper DL, Hauser SL, Longo DL, Jameson JL, editors. Harrison's Principles of Internal Medicine (Seventeenth Edition). New York: McGraw Hill, Health Professors Division, 2008; p. 2250-55.

5. Davies TF, Larsen PR. Thyrotoxicosis. In: Larsen PR, Kronenberg HM, Melmed S, Polonsky KS, editors. Williams Textbook of Endocrinology (Tenth Edition). Philadelphia: Saunders by Elsevier, 2003; p. 374-421.

6. Kopp P, Jameson JL. Thyroid disorders. In: Jameson JL, Collins FS, editors. Principles of Molecular Medicine. New Jersey: Humana Press, 1998; p. 459-73.

7. Cappola A, Miller M, Gambert S. Thyroid disease in the elderly. In: Cooper D, editor. Medical Management of
Thyroid Disease (Second Edition). New York: Informa Healthcare, 2008.

8. Utiger RD. The thyroid: physiology, thyrotoxicosis, hypothyroidism and the painful thyroid. In: Felig P, Baxter JD, Frohman LA, editors. Endocrinology and Metabolism (Third Edition). New York: McGraw Hill, 1995; p. 435-519.

9. Waspadji S. Pendekatan klinis pengelolaan tirotoksikosis. Penatalaksanaan Penyakit-Penyakit Tiroid Bagi Dokter. Jakarta: Perkeni Jaya, 2008.

10. Schraga E, Kularni R. Hyperthyroidism, thyroid storm and Graves disease [Homepage on the Internet]. 2013 [Cited 2013 Apr]. Available from: http://emedicine.medscape.com/article/ 767130-overview\#a0199

11. Dillmann W. Cardiac function in thyroid disease: clinical features and management considerations. Annals Thoracic Surgery. 2000;56:S9-15.

12. Fitzgerald PA. Endocrinology. In: Tierney LM. McPhee SJ, Papadakis MA, editors. Current Medical Diagnosis and Treatment. New York: McGraw Hill, 2006; p. 1135-43.

13. Price SA, Wilson ML. Pathophysiology Clinical Concepts of Disease Processes (Fourth Edition). New York: McGraw Hill, 1990; p. 333-44.

14. Wardhini S, Suharto B. Hormon tiroid dan antitiroid. In: Ganiswara SG, Setiabudy, Suryatna FD, Purwantyastuti, Nafrialdi, editors. Farmakologi dan Terapi (Edisi Keempat). Jakarta: Gaya Baru, 2003; p. 420-31.

15. Kahaly G, Dillmann W. Thyroid hormone action in the heart. Endocrine Reviews. 2005;26(5):704-28.

16. Pantalone KM, Nasr C. Approach to a low TSH level: Patience is a virtue. Cleveland Clinic Journal of Medicine. 2010;77:803-11.

17. Radja M, Hooley P, Howlett J. A case of hyperthyroid cardiomyopathy. Perspectives in Cardiology. 2003:15-9.

18. Kalra S, Khandelwal S, Goyal A. Clinical scoring scales in thyroidology: a compendium. Indian Journal Endocrinology Metabolic. 2011;15(2);89-94.

19. Clutter WE. Hyperthyroidism. In: Green GB, Harris IS, Lin GA, Moylan KC, editors. The Washington Manual of Medical Therapeutics (Thirty-first 
Edition). Philadelphia: Lippincott Williams \& Wilkins, 2004; p.492-6.

20. Semiardji G. Penyakit kelenjar tiroid. Gejala diagnosis dan pengobatan. Jakarta: Balai penerbit FKUI, 2003; p. 4-12.

21. Groote P, Ennezat P, Mouquet F. Bisoprolol in the treatment of chronic heart failure. Vascular Health and Risk Management. 2007;3(4):431-9.

22. Camm J. Guidelines for the management of atrial fibrillation. The Task Force for the Management of Atrial Fibrillation of the European Society of Cardiology (ESC). France, 2012.

23. Fadel B, Ellahham S, Ringel M, Lindsay J. Hyperthyroid heart disease. Clinical Cardiology. 2000;23:402-8.

24. Dinarti L, Suciadi L. Stratifikasi risiko dan strategi manajemen pasien dengan fibrilasi atrium. Majalah Kedokteran Indonesia. 2009;59(6):277-84.

25. Bhagavan HN. Coenzyme $\mathrm{q} 10$ for heart disease [serial online]. 2003 [cited 2013 March 15]. Available from http://www.thewallachfiles.com/inform ation center/coenzyme_q10.htm

26. Marzilli M. Trimetazidine: a metabolic agent for the treatment of stable angina.
European Heart Journal Supplements. 2001;3:12-5.

27. Soegondo S. Panduan Pelayanan PAPDI. Jakarta: Pusat Penerbitan Departemen Ilmu Penyakit Dalam FKUI, 2005.

28. Djokomoelyanto R. Kelenjar tiroid, hipotiroidisme dan hipertiroidisme. In: Sudoyo AW, Setiyohadi B, Alwi I, Simadibrata M, Setiati S, editors. Buku Ajar Ilmu Penyakit Dalam Jilid 3 (Edisi Kelima). Jakarta: Pusat Penerbitan Departemen Ilmu Penyakit Dalam FKUI; 2009: p. 1993-2007.

29. Shahab A. Penyakit Graves (struma diffusa toksik), diagnosis dan penatalaksanaannya. In: Seri Endokrinologi-Metabolisme. Jakarta: PIKKI, 2002; p. 9-18.

30. Izumi K, Kondo S, Okada T. A case of atypical thyroid storm with hypoglycemia and lactic acidosis. Endocr J. 2009;56(6):747-52.

31. Jiang Y, Hutchinson KA, Bartelloni $P$, Manthous A. Thyroid storm presenting as multiple organ dysfunction syndrome. Chest. 2000;118:877-92.

32. Yamaji Y, Hayashi M, Suzuki Y, Noya K, Yamamoto $\mathbf{O}$. Thyroid crisis associated with severe hypocalcemia. Jpn J Med. 1991;30(2):179-82. 